\title{
Prevalence And Levels Of Soil Transmitted Helminths (Sth) Infection Associated With Gender And Age In Cakung Public Elementary School On District Binuang Serang Banten Area
}

\author{
$\underline{\text { Titis Cresnaulan Desiyanti }}^{1,)^{*}}$, Ambar Hardjanti ${ }^{1}$, Zwasta Pribadi Mahardhika $^{3}$, Putri \\ Rachmawati ${ }^{1}$, Rizki Fauzi Rahman ${ }^{1}$, Yolanda Intan Farellina ${ }^{1}$, Yudi Wahyudi ${ }^{1}$ \\ ${ }^{1}$ Faculty of Medicine, Yarsi University \\ ${ }^{a)}$ tcresnaulan@yahoo.co.id
}

\begin{abstract}
Underdeveloping countries have a high prevalence of worm infection. Some causes of this condition are poor environmental sanitation, lack of personal hygiene, consuming food contaminated with worm's eggs and low levels of socioeconomic education. More than 1,5 billion people or $24 \%$ of world population are infected by Soil Transmitted Helminths (STH). Almost 60-90 \% Indonesian children have STH infection in their bodies. The increases of this condition can disturb the next figure of the country. The aims of the study is to figure out the prevalence and STH infection levels and also to see the correlation in every variable with gender and age. The study was conducted at Cakung Public Elementary School in Binuang District Serang Banten Area on 2016 with cross sectional method. Samples of feces came from the student of public elementary school, with a total collected sample was 55 samples that have complied the inclusion criteria such as 6-12 years old and approved the informed consent form. Beside that, The sample also have complied the exclusion criteria such as consume worming medicine, didn't collect feces, and died. Sampling inspection conducted by the method of KatoKatz. The result of these study was found that nine student have STH infection or 16,4\% prevalence with mild levels. Species of STH which found are Ascaris lumbricoides (68,75\%), Trichuris trichiura (31,25\%), and didn't find any Necator americanus's species. The highest frequency was founded on 6-8 years old. Based on statistical calculations there is no significant association between the prevalence and levels of STH infection with gender and age.
\end{abstract}

Keywords : Soil Trasnmitted Helminths (STH), Elementary School, Prevalence and Levels

\section{INTRODUCTION}

More than 1.5 billion people or $24 \%$ of the world's population was infected of Soil Transmitted Helminths (STH), in both of the tropical and subtropical regions. High prevalence of infection found in sub-Saharan Africa, America, China, and Southeast Asia. STH is transmitted through the egg shape of human feces-contaminated the soil, especially in environments with worst sanitation ${ }^{1}$. The prevalence of Ascarislumbricoides in Indonesia reached over $70 \%$ in some villages, including the village on Sumatra (78\%), Borneo (79\%), Sulawesi (88\%), West Nusa Tenggara $(92 \%)$ and West Java $(90 \%)^{2}$. In addition, the prevalence of worm infection in children in Indonesia is still quite high, ranging from $60-90 \%{ }^{3}$. The result of worm infection on 
2002 in Indonesia by Ditjen P2PL mention that $31.8 \%$ of elementary school students suffered worm infection ${ }^{4}$. Worm infection causes anemia, malnutrition, impaired growth and intelligence. Persistent infection will reduce the quality of human resources, and it can occur at any age, either in infants, children or adult. Therefore, the data and the prevalence of infection is important for prevention and elimination of intestinal worms, but unknown prevalence and infection rates for primary school pupils in the District Binuang Serang district, Banten. This study aims to determine the prevalence and levels of Soil Transmitted Helminths Associated with gender and age to the students at Cakung Public Elementary School On District Binuang Serang Banten Area.

\section{METHODS}

This study is an observational study conducted with cross sectional approach. The population in this study were students of Cakung Public Elementary School On District Binuang Serang Banten Areain 2016. The sample was part of the population who have the inclusion criteria are 6-12 years old and fill out the informed consent for respondents and respondent's parents. While Exclusion criteria such as taking worming tablets during the last 6 months, did not return samples of feces, and died. The minimum sample required in this study are as many as 38 samples. To determine the sample, first, therespondent was giveninformed consent sheet. And then, for the respondent who accepted for the sample was given the pot of feces and the procedure paper. Samples have been collected directly analyzed by researchers and two laboratorian on Laboratory in Faculty of Medicine, Yarsi University. The method for analysis this study did with Kato Katz method. Preparation is necessary for this method is set up tools and materials such as malachite green, glycerol, cellophane tape, oil paper, wire screen, perforated cardboard, glass objects, sticks, and microscopes. Then the first thing to do was to prepare a solution of malachite green in advance by mixing malachite green powder $3 \%$ of $1 \mathrm{ml}$ to $100 \mathrm{ml}$ glycerol and $100 \mathrm{ml}$ of aquadest, then soak the cellophane tape that already cut in a pieces to the malachite green solution for at least 24 hours. After that, a feces sample to be observed is placed on paper oil then filtered using filter paper, measured with a perforated carton in order to get the appropriate gram, and put on the object glass and cellophane tape affixed thereon to the observed using a microscope. Chi squre tests were used to limit the significance if $p<0.05$, which means that there is a relationship between two variables tested and if $p>0.05$ there was no correlation between the two variables were tested.

\section{RESULTS}

There were collected 55 samples of child student who has accepted the criteria and the results, nine children (16.4\%) were infected STH, whereas 46 children $(83.6 \%)$ are not infected (Table 1). Type of STH's eggsthat found wereAscaris lumbricoidesobtained in three children (5.5\%) and Trichuris trichiura obtained in 6 children (10.9\%) and zero for hookworm (Table 1). Based on the WHO criteria are expressed the result with mild infection because the number of STH worm eggs that found in each type, no more than the numbers on a classification of each type (Table 2). 
Table 1. Prevalance of Soil Transmitted Helminths (STH) infection and Kind of STH (A. lumbricoides, T. trichiura, and Hokworm)

\begin{tabular}{cccc}
\hline $\begin{array}{l}\text { Levels of } \\
\text { Infection }\end{array}$ & A.lumbricoides & T. trichiura & Hookworm \\
\hline Mild & 3 & 6 & - \\
moderate & - & - & - \\
Severe & - & - & - \\
\hline
\end{tabular}

Table 2. Level of infection of Ascaris lumbricoides, Trichuris trichiura, and Hookworm

\begin{tabular}{ccc}
\hline Infected & $\mathrm{N}$ & $(\%)$ \\
\hline Ascaris lumbricoides & 3 & \\
Trichuris trichiura & 6 & $16,4 \%$ \\
Hookworm & 0 & $0 \%$ \\
Not Infected & 46 & $83,6 \%$ \\
\hline Total & 55 & 100 \\
\hline
\end{tabular}

Associated between gender and age with STH infection showed on $3^{\text {rd }}$ and $4^{\text {th }}$ table. The result of Chi Square test showed that there is no Associated sense between gender and age with STH infection $(p>0,05)$.

Table 3. Corellation between Number of Age with STH Infection.

\begin{tabular}{ccc}
\hline & \multicolumn{2}{c}{ STH Infection } \\
\cline { 2 - 3 } & Positive & Negative \\
\hline $6-8$ & 5 & 20 \\
$9-12$ & 4 & 26 \\
\hline Total & 9 & 46 \\
\hline
\end{tabular}

Table 4. Corellation between Gender with STH Infection

\begin{tabular}{ccc}
\hline \multirow{2}{*}{ Gender } & \multicolumn{2}{c}{ STH Infection } \\
\cline { 2 - 3 } & Positive & Negative \\
\hline boys & 4 & 20 \\
girls & 5 & 26 \\
\hline Total & 9 & 46 \\
\hline
\end{tabular}

\section{DISCUSSION}

Research conducted in Cakung Public Elementary SchoolOn District Binuang Serang Banten Area2016 showed the prevalence of ascariasis worm infection and trichuriasis of $16.4 \%$ and based on WHO criteria the rate of infection is mild. Several studies in other areas also showed 
the prevalence and infection rates are getting lower. It can be seen from the study conducted in several places in Indonesia such as Chadijah et al. study, In 2009 in Central Sulawesi Palu result prevalence of worm infection of 51.59\% ${ }^{6}$ Malinau Research in South Kalimantan in 2012 showed a decrease in the prevalence rate infections are quite large, to $6.16 \%{ }^{7}$. research in SDN Tarigu Cipanas in 2012 also showed the results of the prevalence of infection Ascaris lumbricoides and Trichuris trichiurarespectively by $2.0 \%$ and $16.7 \%^{8}$. Based on some of the research results, it is known that the prevalence of worm infection tends to decline from year to year.

The mild level of worm infection in Cakung Public Elementary School On District BinuangSerangBanten Area can be caused by several factors such as temperature changes due to the "global warming". Changes in temperature which could cause soil conditions that consistency to be different, but as we known that worms STH can develop optimally in the tropical climate with an optimal temperature for the eggs of Ascarislumbricoides $25^{\circ} \mathrm{C}, 30^{\circ} \mathrm{C}$ for Trichuristrichiura eggs, $23-25^{\circ} \mathrm{C}$ for larvae Ancylostomaduodenale and $28-32^{\circ} \mathrm{C}$ larvae of Necatoramericanus ${ }^{9}$. In addition for the tropical climate, footwear usage habits while doing the activity and habits of latrine use in children may be a factor decreasing pupil worm infection rate of $^{7}$.

Type of worm eggs are most commonly found in Cakung Public Elementary School Serang is Trichuris trichiura then Ascaris llumbricoides. The high infection of Trichuris trichiura always followed by high Ascaris lumbricoides infection that can be caused by both worms have the same environmental conditions, namely in the temperate humid. Besides these two types of worms has a same way of infected, namely to mature eggs ingested. Research conducted by Chasanah and Sumekar in 2015 showed that the results for Ascaris lumbricoides 52.72\% and $42.72 \%$ for Trichiuris trichiura ${ }^{10 .}$ As for the research conducted at several elementary schools in Indonesia showed the highest prevalence of worm Ascaris lumbricoides (74.70 to 80\%) and Trichuris trichiura (25.30 to $68.42 \%)^{7}$.

Worm disease can occur in all age groups and can occur in boy as well as girl ${ }^{11}$. This is consistent with some of the data that exist in Indonesia, with $60 \%-80 \%$ occur at primary school age (7-15 years) ${ }^{12}$. Other research data conducted by Agustaria in 2008 in an elementary school in Samosir showed $48.5 \%$ of infections occurred in children aged 6-8 years, 39\% aged 9-11 years and $11.9 \%$ in the age group $\geq 12$ years. Research conducted by Sandy et al. 2015 Elementary School District Karoom Papua Arso with the percentage of STH infections in boys $27.2 \%$ and girls $32.2 \%$. In addition, research conducted at the Primary School in Samosir shows the results $57.4 \%$ boys and $42.6 \%$ of girls were infected with worms. Research conducted inCakung Public Elementary School On District Binuang Serang Banten Area had positive results in five children (55.6\%) aged 6-8 years and four children (44.4\%) aged 9-12 years. Both sexes are equally experienced worm infection that five people on girls and four people on male students. Statistical calculations no relationship was found between age and gender because the value of $\mathrm{p}>0.05$.

\section{CONCLUSION}

Obtained from the data it can be concluded that the prevalence and infection rates occurring in students at Cakung Public Elementary SchoolOn District Binuang Serang Banten Areaare 
relatively low and not found a relationship between the prevalence and levels of STH infection by gender and age, based on p values were obtained more than 005 .

\section{SUGGESTION}

Informed consent sheet is required in this study to determine the sample was appropriate with criteria or not. It is currently giving informed consent sheets are advised to immediately provide to parents in order to receive information in clear and true. Having good coordination with the school can help the collection of samples without any problems.Preparation of malachite green and soaking cellophane tape better be longer in order to get the green color is more real.

\section{REFERENCE}

1. World Health Organization (WHO). Intestinal worms, soil transmitted helminths. Ganeva. 2015.

2. Inge S., Is S.I., Pudji K.S., Saleha, S.Buku Ajar Parasitologi Kedokteran Edisi Keempat. Jakarta : Badan Penerbit Fakultas Kedokteran Universitas Indonesia ; 2011.

3. Ershandi, R. Prevalensi Nematoda Usus Golongan Soil Transmitted Helminthes (STH) Pada Peternakan di lingkungan Gatep Kelurahan Ampenan Selatan. 2014. Media Bina Ilmiah ; Vol 8 (5) : 1-6. Available from http://www.lpsdimataram.com.

4. Reshka, RM., Selfi, R.R., and Elmatris SY. Hubungan Infeksi STH dengan Status Gizi pada Murid SDN 29 Purus Padang. 2015. Andalas Journal ; Vol 4 (2) :1- 6. Available from http://jurnal.fk.unand.ac.id.

5. Faridan,K., Marlinae,L. and Audhah N.A. Factors correlated with helminthiasis incidence on students ofCempaka 1 Elementary School Banjarbaru. 2013. Journal Epidemiologi dan Penyakit Bersumber dari Binatang; Vol. 4 (3): 121- 127. Available from http://ejournal.litbang.depkes.go.id

6. Siti, C., Hayani,A., Junus, W., and Made A.N. Kejadian Penyakit Cacing Usus di Kota Palu dan Kabupaten Dongala, Sulawesi Tengah. 2013. Epidemiology and Zoonosis Journal; Vol 4. (4): 181-187. Available from http://download.portalgaruda.org.

7. Budi, H., Lukman, W., and Juhairiyah. Prevalence of Soil Transmitted Helminthes (STH) in Primary School Children in Subdistrict of Malinau Kota, District of Malinau, East Kalimantan Province. 2014. Epidemiology and Zoonosis Journal; Vol 5 (1): 43 - 48. Available from http://www. ejurnal.litbang.depkes.go.id

8. Patra,P. Prevalensi, Intensitas Infeksi dan Faktor Soil Transmitted Helminths pada anak sekolah dasar dan anggota keluarga di Jakarta dan Cipanas.2012.Thesis. Universitas Indonesia Library. Available from http://lib.ui.ac.id

9. Djaenudin, N. Parasitologi Kedokteran : Ditinjau Dari Organ Tubuh Yang Diserang. Jakarta : EGC ; 2009.

10. Siti, U.C., and Ariana, S. Analisis Resiko Soil Transmitted Helminths di Sekolah Dasar di Kecamatan Padaherang Kabupaten Ciamis, Jawa Barat. 2015. KESMAS Journal; Vol 9(1): 37-44. Available from http://journal.uad.ac.id

11. Agustaria, G. Faktor-faktor yang Berhubungan Dengan Angka Kejadian Kecacingan Pada Anak Sekolah Dasar di Desa Tertinggal Kecamatan Pangururan Kabupaten Samosir Tahun 2008. 2008. Thesis. USU digital library. Available from http://respiratory.usu.ac.id

12. Rawina, W., Mulyati, and Hendri, A. Hubungan Sanitasi Diri Dengan Kejadian Kecacingan Pada Siswa SDN X Paseban, Jakarta Pusat. 2012. Faculty of Medicine UKI University 
Magazine; Vol. XXVII (2): 60-68. $\quad$ Available from http://www.majalahfk.uki.ac.id/assets/majalahfile/artikel/2012-02-artikel-01.pdf

13. Semuel, S., Sri, S., and Soeyoko. Analisis Model Faktor Risiko Yang Mempengaruhi Infeksi Kecacingan Yang Ditularkan Melalui Tanah Pada Siswa Sekolah Dasar Di Distrik Arso Kabupaten Keerom, Papua. 2015. Media Litbangkes Maret; Vol. 25 (1): 1 - 14. Available from http://ejournal.litbang.depkes.go.id/index.php/MPK/article/download/4091/3880 [28 April 2016]. 